\title{
The Effect of Salinity on the Embryonic Development of the Giant Freshwater Prawn Macrobrachium rosenbergii (De Man, 1879) Under Laboratory Conditions
}

\author{
Erika Iolany Camacho Chuy ${ }^{1}$, Juan Lorenzo Reta Mendiola ${ }^{2}$, Eduardo Zarza Meza ${ }^{1,}$ * \\ ${ }^{1}$ Facultad of Biological and Agricultural Sciences, Poza Rica-Tuxpan Region, Universidad Veracruzana, Veracruz, Mexico \\ ${ }^{2}$ College de Posgraduados, Campus Veracruz, Agroecosistemas Tropicales, Veracruz, Mexico
}

\author{
Email address: \\ ezarza@uv.mx (E. Z. Meza) \\ *Corresponding author
}

\section{To cite this article:}

Erika Iolany Camacho Chuy, Juan Lorenzo Reta Mendiola, Eduardo Zarza Meza. The Effect of Salinity on the Embryonic Development of the Giant Freshwater Prawn Macrobrachium rosenbergii (De Man, 1879) Under Laboratory Conditions. American Journal of Bioscience and Bioengineering. Vol. 9, No. 3, 2021, pp. 60-67. doi: 10.11648/j.bio.20210903.11

Received: April 8, 2021; Accepted: April 23, 2021; Published: May 8, 2021

\begin{abstract}
Prawn farming is a highly profitable activity given the high level of commercial interest associated with prawn species. Macrobrachium rosenbergii, known as the giant freshwater prawn, is the largest prawn of its genus and presents great adaptability in terms of the handling it requires. Given the foregoing, research is ongoing to broaden knowledge in order to improve the quality of production for this species in northern region of the state of Veracruz, Mexico, by studying the behavior of these anadromous organisms from the first stages of life onwards. The experimental design of the present study involved placing gravid females in incubators with different levels of salinity (5,9, and $12 \mathrm{psu})$ and a control containing freshwater, with three replicas conducted per salinity treatment, giving a total of 12 experimental units with a female in each. In general terms, the results obtained showed, in general terms, a total of 13 days for the embryonic development of M. rosenbergii. Although a decreasing volume of eggs was observed as the salinity increased, the percentage of hatchings was higher at 9 psu, with $65 \%$, than for the other salinity treatments. The results also reveal that the 12 psu treatment obtained a better survival percentage $(12.06 \%)$ than the other treatments. The different biotic factors to which the organisms may be exposed are also considered in the present study.
\end{abstract}

Keywords: Macrobrachium Rosenbergii, Embryonic Development, Larvae, Salinity

\section{Introduction}

Over recent years, aquaculture has grown significantly due to its increasing importance as an alternative to fishing, as it has a lower environmental impact. In light of estimates that, by the year 2050, demand for aquaculture resources will stand at approximately 80 million tons [3], interest in improving the quality of aquatic organism cultures has increased, leading to the search for more knowledge on the processes involved in order to increase production. It should be noted that crustaceans now represent a high percentage of the commercial value of aquaculture in Mexico [27]. The genus of the Palaemonidae family that attracts the most interest is Macrobrachium, due to the commercial value of its biological characteristics, such as its size and weight, and environmental characteristics, in that the genus occurs in the tropical and subtropical regions of the world [32]. According to $[17,33]$, ten Macrobrachium species occur in Mexico, of which solely five are of commercial value: Macrobrachium americanum (Bate, 1868) and Macrobrachium tenellum (Smith, 1871), occurring in the Pacific Ocean and the Gulf of Mexico; Macrobrachium acanthurus (Wiegmann, 1836); Macrobrachium carcinus (Linnaeus, 1758); and, as an exotic species, Macrobrachium rosenbergii (De man, 1879), which is found in aquaculture farms in different regions of the Mexican Republic. Commonly known as the giant freshwater prawn or the giant river shrimp, Macrobrachium rosenbergii is subject to great commercial demand [29].

Growing to a maximum total length of $320 \mathrm{~mm}$ for males and $250 \mathrm{~mm}$ for females [17], this species, the largest of its 
genus and native to the Indo-Pacific, was introduced to Mexico due to its size and easy adaptability to farming [23]. After reproducing in freshwater and requiring salinity for their life processes [25], prawn species descend to brackish regions to hatch their eggs and continue their larval development [24]. With osmoregulation playing a fundamental role in embryogenesis, various studies have found that the embryonic membrane of crustaceans is responsible for protecting osmosis during embryogenesis, in relation to/via/as a function of increased levels of the enzyme $\mathrm{Na}+/ \mathrm{K}+$-ATPasa [5]. Therefore, research has sought to identify the optimal salinity requirements, observing the growth of M. rosenbergii embryos at different salinity levels, in order to ascertain how this physicochemical parameter influences the development of the embryo and to identify the ideal salinity level for a healthy organism with the desired characteristics. This information would enable producers to improve their management of cultures of this species and, thus, obtain organisms of a higher quality.

Reported the first observations of the importance of saline water to the early life stages of $M$. rosenbergii. [16] In a study comprising six salinity treatments $(0,6,9,12,16$, and $18 \mathrm{psu}$ ) with three replicas each and an average embryonic duration of 22 days, [4], found that embryonic development tended to decrease as salinity increased. They also found an optimal salinity range of $12 \mathrm{psu}$, given that this range presented the highest survival percentage. [28], report that $M$. malcolmsonii embryos incubated in vitro hatch better at a minimum salinity of $0.5 \mathrm{psu}$ than in salinities of $2,4,6,8$, and $10 \mathrm{psu}$, observing mortality in the first three embryonic stages and concluding that $0.5 \mathrm{psu}$ is a good level of salinity.

Carried out a study in Argentina on the effect of salinity on the embryonic development of two species of estuarine crabs (Chasmagnathus granulata and Cyrtograpsus angulatus) of the South-West Atlantic, which are cultivated in vitro due to the fluctuations in salinity present along the Mar del Plata coast. Working with salinities ranging from 12 to $44 \mathrm{psu}$, they observed that the egg tends to shrink as salinity increases, thus identifying that the volume of the embryos was inversely proportional to the salinity to which they were exposed. [2]

Developed a manual on $M$. rosenbergii for the Food and Agriculture Organization of the United Nations (FAO), which indicates that maintaining a salinity of $5 \mathrm{psu}$ and a $\mathrm{pH}$ of 7.0 to 7.2 for gravid females until hatching ensures an improved hatching rate [25]

Carried out two treatments for prawns from the Gulf of Mexico, M. acanthurus and M. carcinus. After applying both drastic and gradual changes in salinity, they observed significant differences in mortality and a strong relationship between the survival of these species and the amount of saline water supplied to the medium [30]

In research conducted in Chile, [34], studied the daily embryonic development of the river prawn Cryphiops caementarius (Decapoda: Palaemonidae) under laboratory conditions. Applying three different temperature treatments, they conducted daily embryo (3-6) extraction on each female for subsequent observation under the microscope, identifying a total of seven embryonic stages for this species. [10], assessed, in vitro, the effect of salinity on early developing $C$. caementarius embryos taken from one single female, applying four treatments $(0,10,20$, and $30 \mathrm{psu})$ in $400 \mathrm{ml}$ incubators, with three corresponding replicas comprising 200 embryos each. Salinities of 0 and 30 psu did not affect the development of the embryos until the sixth embryonic stage, while a delay in the presentation of stages seven and eight was observed for the 10 and 20 psu treatments. They found that a salinity of $30 \mathrm{psu}$ caused death at Stage 7, while, at 0 psu, $70.3 \%$ of the embryos survived and the larvae were normal; however, at $10 \mathrm{psu}$ and $20 \mathrm{psu}, 13.5 \%$ and $7.9 \%$, respectively, of the larvae were able to hatch, although they did present deformations. [14], in research conducted in Egypt, described the embryonic changes occurring during the development of $M$. rosenbergii, reporting an embryonic duration of 20 days, although it should be taken into account that, in their study, the eggs were placed in freshwater.

In Peru [1] conducted a study on the embryonic development of $M$. americanum, placing gravid females in incubators and gradually increasing the salinity by 1 psu increments until reaching 13 psu. They found that embryogenesis lasted for 17 days at $28^{\circ} \mathrm{C}$, after which, at the point of hatching, the larvae were placed in $5 \mathrm{~L}$ containers with salinity levels of $1,12,16,20,24$, and 26 psu. They observed mortality at 1 psu and $100 \%$ survival levels at the other salinity levels. This finding highlights the importance of salinity for larval metamorphosis, wherein the higher the salinity, the higher the survival rate. However, the feed (Artemia sp. nauplii) used in the foregoing study was inadequate, with the individuals studied solely reaching the third zoeal stage.

\section{Material and Methods}

The present study was conducted in the aquaculture laboratory of the Postgraduate College, Campus Veracruz, in the state of Veracruz, Mexico. Fifty breeding individuals were selected at a ratio of 1:3 (male / female) and placed in freshwater in a $4,580 \mathrm{~L}$ circular geomembrane tank, $2.70 \mathrm{~m}$ in diameter and $80 \mathrm{~cm}$ high, with oxygenation supplied by means of a $1 / 2$ HP blower motor, with $15-20 \mathrm{~cm}$ long PVC tubes, two inches in diameter, then introduced as a shelter for the individuals. Green burlap was also used to subdivide the tank along its length to provide a mating area for the males. The specimens were fed once a day with pelletized commercial shrimp feed (of the brand El Pedregal), at a $40 \%$ ratio, and, eventually, tilapia fillet, viscera, and fresh gills.

Once the females had been fertilized, a biometry was performed to obtain their corresponding length and weight, measuring from the tip of the rostrum to the rear end of the telson for the total length [14], thus enabling the calculation of the weight and length ratio for females both with and without eggs.

Three treatments were applied, with salinities of 5, 9, and $12 \mathrm{psu}$, while a fourth freshwater $(0 \mathrm{psu})$ treatment served as 
the control. [15] Three replicas corresponding to each of the three treatments were carried out, giving a total of 12 experimental units with one female per replica.

The ovigerous females were placed in $65 \mathrm{~L}$ rectangular tanks [18], each of which was equipped with an oyster shellbased cascade-type biological filtration system, a fine mesh bag used as netting to avoid leaks at the base, a thermostat, and an aquarium aerator stone. The saline water was transported directly from Mata de Uva Beach, in the municipality of Alvarado, in the state of Veracruz, and was disinfected with $0.5 \mathrm{ml}$ sodium hypochlorite for each liter of saline water and then aerated for $24 \mathrm{~h}$. Five drops of sodium thiosulfate pentahydrate was then added per liter of water to remove the residual chlorine. The embryos carried by each ovigerous female were then checked every $72 \mathrm{hrs}$ to prevent possible stress from affecting egg development.

The $\mathrm{pH}$ level was measured every morning, registering values of $7 \pm 0.4$, while the dissolved oxygen level was recorded at $4.15 \pm 1.40 \mathrm{ppm}$ and the temperature was $28.2 \pm$ $3.0^{\circ} \mathrm{C}$.

The morphological description of the embryos was undertaken based on the following studies on the embryonic development of palaemonids: [16, 20, 21, 10, 12, 14, 9]; and, [19]. The development phase was expressed as a percentage, according to the criteria described by [11]. Using the Image $j$ digital processing program, the width (a) and length (b) of the eggs was obtained and then entered into a database produced using Excel software, while the volume (v) of ellipsoid bodies was calculated using the following formula:

$$
v=\frac{\pi}{6} \cdot b^{2} \cdot a[31]
$$

Once the larvae had hatched from the eggs, volumetric tests were carried out to calculate the number of hatchings, following the procedure described in [25], manual, in which ten samples of the homogeneous mixture are taken from the tank in a $100 \mathrm{ml}$ cup. All the larvae identified in each sample were then counted, after which the total number of larvae observed was multiplied by the number of liters in the tank and divided by the total number of liters comprising the samples, which corresponded to one liter. This procedure was applied for all the experimental units. Reproductive success is expressed via the relationship between the rates of embryo production and hatching [19], wherein the hatching percentage was obtained by dividing the number of larvae observed for each treatment by the total number of larvae hatched. The survival rate was obtained using the following formula, as proposed by [32]:

$$
\begin{gathered}
S u \text { rvival }(\%)(S)=100-(\text { o } r g . \text { beginning-or } g . \text { end } / \\
\text { or } g \text {. beginning }) X 100 .
\end{gathered}
$$

\section{Results}

The ovigerous females ranged from $10.5 \mathrm{~cm}$ to $14 \mathrm{~cm}$ in length, giving an average $12.3 \pm 1$, which was also within the length range for females without embryos. In terms of weight, the ovigerous females ranged from $18 \mathrm{~g}$ to $38 \mathrm{~g}$, with an average of $24.8 \pm 5.4 \mathrm{~g}$, while their final weight corresponded to a minimum of $17 \mathrm{~g}$ and a maximum of $34 \mathrm{~g}$,

\begin{tabular}{|c|c|c|c|c|c|}
\hline Treatment & Replicas & $\begin{array}{l}\text { Length of female with } \\
\text { eggs }(\mathrm{cm})\end{array}$ & $\begin{array}{l}\text { Weight of female with } \\
\text { eggs (gr) }\end{array}$ & $\begin{array}{l}\text { Length of female } \\
\text { without eggs }(\mathrm{cm})\end{array}$ & $\begin{array}{l}\text { Weight of female } \\
\text { without eggs (gr) }\end{array}$ \\
\hline 1 (0 ups) & 1 & 12 & 19 & 12 & 17 \\
\hline 1 (0 ups) & 2 & 13.5 & 23 & 13.5 & 20 \\
\hline 1 (0 ups) & 3 & 12.7 & 23 & 12.7 & 22 \\
\hline 1 (5 ups) & 1 & 11.5 & 22 & $11-5$ & 20 \\
\hline 1 (5 ups) & 2 & 11.5 & 24 & 11.5 & 23 \\
\hline 1 (5 ups) & 3 & 11.3 & 24 & $11-3$ & 23 \\
\hline 1 (9 ups) & 1 & 13.8 & 32 & 13.8 & 30 \\
\hline 1 (9 ups) & 2 & 14 & 38 & 14 & 34 \\
\hline 1 (9 ups) & 3 & 12.5 & 24 & 12.5 & 22 \\
\hline 1 (12ups) & 1 & 12.5 & 26 & 12.5 & 24 \\
\hline 1 (12ups) & 2 & 10.5 & 18 & 10.5 & 17 \\
\hline \multirow[t]{2}{*}{1 (12 ups) } & 3 & 12.3 & 24 & 12.3 & 22 \\
\hline & & $12.3 \pm 1$ & $24.8 \pm 5.4$ & $12.3 \pm 1$ & $22.8 \pm 4.8$ \\
\hline
\end{tabular}
with an average of $22.8 \pm 4.8 \mathrm{~g}$ (Table 1 ).

Table 1. Biometry of M. rosenbergii breeding females by treatment.

The egg mass presented different tones as the embryo developed, with a bright orange coloration observed on Day 1, which, by Day 4, had become a notably pale orange tone. By Day 7, the eggs had turned yellow, which, in turn, had been transformed into a brown coloration by Day 10. Finally, on Day 13, the coloration of the eggs was observed as grayish.

The gravid females were measured and weighed, with the first embryonic observation undertaken in order to establish the stage of development of the egg. The segmentation was observed as complete and the surface of the egg appeared lighter than its center, which can be explained by the fact that gastrulation was beginning, thus developing the embryonic primordium. Seventy-two hours later, the metanauplius was observed to have recently appeared, with a transparent trunk (caudal papilla), small reddish chromatophore spots, and ocular pigmentation (optic lobe) of a darker tone also observed, while the appendages were barely visible. The postnaupliar stage had presented by Day 7, with the appendages lengthening and becoming larger, while the 
caudal papilla was observed to be larger and in the shape of the letter $C$. moreover, the telson was now presenting, the chromatophores were developing in more parts of the embryo, the dorsal cardiac vessel was now formed and beating and the eyes were completely differentiated. By Day 10, the embryo had increased considerably in size, its movements increasing as the size of the vitellus decreased, with abdominal segments forming in the trunk, the eyes pedunculated, the heart developing, and the chromatophores now clearly distinguishable.

Finally, by day 13, the larva was fully formed and ready to be introduced into the medium, with the embryo occupying all available space except for the remaining dorsal yolk, while all the thoracic and cephalic appendages covered the ventral side of the egg and the extremities of both the appendages and the telson presented setae. At this point, the eyes were observed to grow larger, while the embryos had finished feeding on the yolk, thus occupying even more space in the egg.

On Day 1, treatments 1 and 4 began with a lower egg volume (0.08 and $0.09 \mathrm{~mm} 3$, respectively) than treatments 2 and 3 (0.12 and $0.11 \mathrm{~mm} 3$, respectively), which had presented a higher initial volume, differences which are significant $(\mathrm{F}=18.262 ; \mathrm{p}<0.01)$. By Day 4 , the volume of the embryos did not present significant differences $(\mathrm{F}=$ $0.913 ; \mathrm{p}=0.438997)$, a variable which was still presenting no significant changes by Day $7(\mathrm{~F}=2.133 ; \mathrm{p}=0.104672)$. By Day 10, the volume of the embryos continued to increase for all treatments, except Treatment 3 , in which the embryo remained the same size, a contrast which was found to be statistically significant $(\mathrm{F}=7.951 ; \mathrm{p}=0.000126)$. By Day 13, the embryos were presenting continuous volume increases, except for Treatment 4 , in which a decrease in volume was observed. However, the foregoing differences were not found to be statistically significant $(\mathrm{F}=2.481 ; \mathrm{p}=$ 0.081328) (Figure 1).

Table 2. Average number of M. rosenbergii hatches observed for the different salinity treatments, corresponding to the number of treatment days.

\begin{tabular}{llll}
\hline Day & T1 (0 ups) & T2 (5 ups) & T3 (9 ups) \\
\hline 1 & $0.876( \pm 0.0046)$ & $0.1245( \pm 0.0128)$ & $0.1195( \pm 0.0104)$ \\
4 & $0.0971( \pm 0.0067)$ & $0.0981( \pm 0.0075)$ & $0.1020( \pm 0.0182)$ \\
7 & $0.1121( \pm 0.0066)$ & $0.1095( \pm 0.0143)$ & $0.0974( \pm 0.0194)$ \\
10 & $0.1338( \pm 0.0216)$ & $0.1199( \pm 0.0088)$ & $0.0975( \pm 0.0215)$ \\
13 & $0.1475( \pm 0.0081)$ & $0.1300( \pm 0.0203)$ & $0.1303( \pm 0.0326)$ \\
& 0.1156 & 0.1164 & $0.0922( \pm 0.0173)$ \\
\end{tabular}

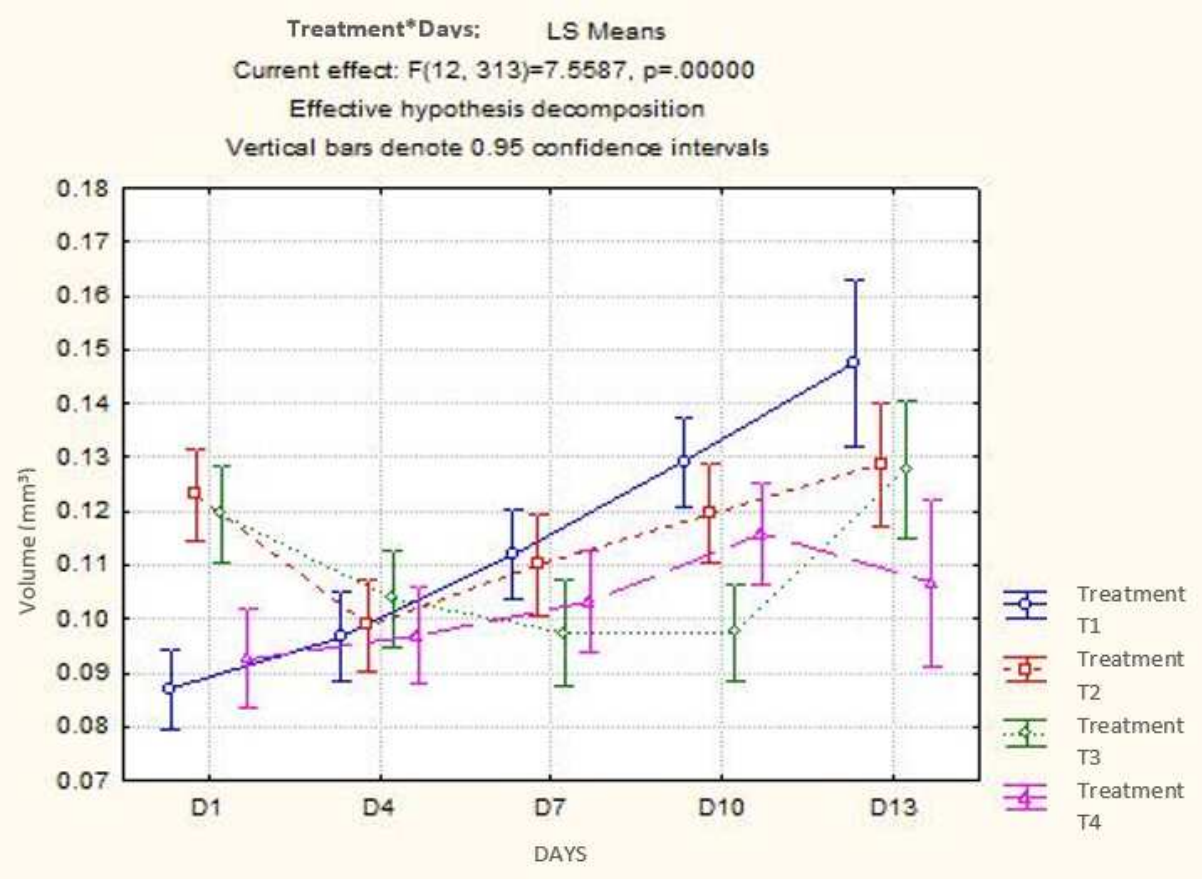

Figure 1. M. rosenbergii embryo volume corresponding to the number of days comprising each treatment.

The highest number of hatchings was observed in Treatment 3 , at a salinity of $9 \mathrm{psu}$, followed by Treatment 4 (12 psu), for which a hatch percentage of $18 \%$ was observed, while the lowest values for this variable were observed for treatments 1 and 2 ( 0 and 5 psu, respectively) (Table 2).
The highest percentage of hatchings was observed for Treatment 3 at a salinity of 9 psu, followed by Treatment 4 (12 psu) with $18 \%$, while the lowest percentages were observed for treatments 1 and 2 ( 0 and 5 psu, respectively. (Figure 2): 


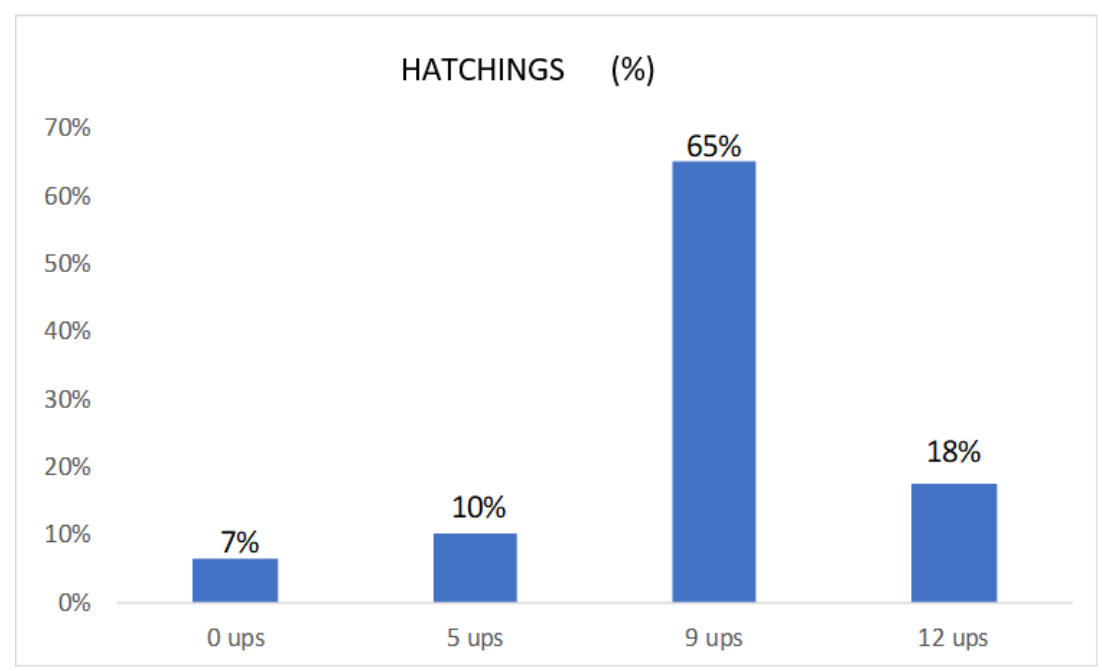

Figure 2. (\%) of M. rosenbergii hatchings obtained for the different salinity treatments.

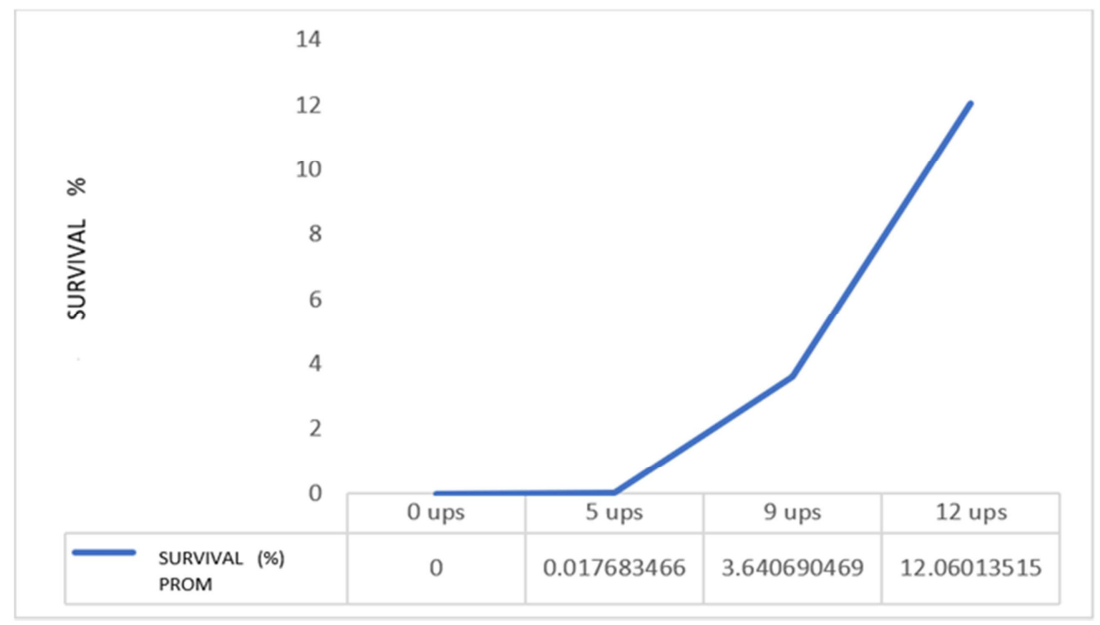

Figure 3. Percentage of survival according to the degree of salinity.

Once the embryo had fully developed, the total number of hatchings for each treatment was calculated, after which the zoea larvae were kept alive until Stage 11 of embryonic development, at which point the experiment was concluded. For each salinity treatment to which $M$. rosenbergii was subject in the present study, it was observed that the survival percentage tends to increase as the salinities increase, rising from zero or null for Treatment $1(0 \mathrm{psu})$ to $0.017 \%$ for Treatment 2 (5 psu), 3.64\% for Treatment 3 (9 psu) and $12.06 \%$ for Treatment 4 (12 psu) (Figure 3).

\section{Discussion}

Physicochemical factors play an important role in the development of organisms, especially in the early stages of life [4]. [26] found that both the commercial quality and growth of Metapenaeus bennettae juveniles is clearly influenced by factors such as temperature and salinity from the organism's first life processes onwards.

In the present study, embryonic development comprised 13 days for all treatments, in contrast to the control treatment $(0$ psu), wherein one of the replicas completed their development 24 hours later. [10], reported a total embryonic duration of 24 days, subjecting the palaemonid Cryphiops caementarius to different salinity treatments at a temperature of $22.5 \pm 1.5^{\circ} \mathrm{C}$, a finding which contrasts to the results reported for Macrobrachium. [4] reported an embryonic development of 20 days, identifying a trend where, as salinity increases, the hatching time for $M$. rosenbergii embryos reduces, a finding which contrasts with that obtained by the present study. While there are similarities between the two studies in terms of species and treatments, there are also significant differences, with [4], applying a temperature of 27 $\pm 1{ }^{\circ} \mathrm{C}$ and the present study applying an average temperature of $29.5^{\circ} \mathrm{C}$. The foregoing also corresponds to the findings obtained by [13], who found that the embryonic development of M. amazonicum lasted 12 to 15 days at $30 \pm$ $1{ }^{\circ} \mathrm{C}$ and 19 to 24 days at $24 \pm 1^{\circ} \mathrm{C}$. The morphological characteristics observed in the present study corresponded to those reported by [13], with the one difference that the eggs obtained for Treatment $1(0 \mathrm{psu})$ in the present research tended to become more fragile to handling as the days passed. The foregoing contrasts with [1], who observed the conclusion of the embryonic development of $M$. americanum 
after 17 days at $28.1^{\circ} \mathrm{C}$ (a different temperature than that applied in the present research), clearly indicating, at a species level, different durations for the first stages of life of these organisms.

Reported an embryonic duration of 20 days for $M$. rosenbergii and observed various egg mass tones: bright orange; yellow; pale brown; and, dark brown. [14] In contrast to that found by the present research, they observed five different colorations, the first two of which are similar to those that we observed, while the last two were different, with the penultimate a brownish yellow and the last tending to be paler. Similarly, [1], described three types of coloration in $M$. americanum eggs over the course of embryonic development, starting with bright orange and followed by light brown and, finally, gray. This finding is explained by the increasing size of the eyes and the fact that, as the embryos finish feeding on the yolk, they acquire a higher proportion of space in the egg, as described by [7] and [22].

This difference in egg coloration is probably due to the different geographical locations in which the above described studies were carried out [4].

A constantly increasing egg volume was observed for Treatment $1(0 \mathrm{psu})$ of the present study, rising from 0.0876 to $0.1475 \mathrm{~mm}$, with this treatment observed to have produced the highest volume by the end of the study. This finding contrasts with [10], wherein, despite similar volume increases being observed for $C$. caementarius in freshwater (0.0665-0.1170 $\mathrm{mm} 3)$, the last embryonic stage saw a greater volume increase in eggs incubated at 10 and 20 psu $(0.0640-0.1192$ and $0.0669-0.1201 \mathrm{~mm} 3$, respectively). They also describe a phenomenon similar to that found in the present study, where, while greater volume was obtained, shrinkage was observed at Stage 5 (Day 7) of embryonic development, which was then followed by further increases in volume. Said differences in volumetric behavior in the eggs may be due to the differences between the genera studied. The eggs obtained from the control treatment $(0 \mathrm{psu})$ in the present study were larger than those obtained from the different salinity a treatment, which also concurs with [28], who reported that the size of $M$. malcolmsonii eggs tends to decrease as salinity increases. This may be due to osmotic stress, expressed via cell shrinkage at higher salinities. [2], report that osmotic tolerance in crustaceans depends on the embryo's external membrane inside the egg, the semi-permeability of which decreases when the embryonic membranes are being formed and then increases when they are fully formed. They also observed a tendency for lower egg volume as salinity increases, due to the fact that the eggs gradually become larger. The embryos produced by Treatment $1(0 \mathrm{psu})$ in the present study tended to swell, enabling the intracellular passage of more solvents and, thus, causing the egg to swell, which does not necessarily occur due to nutritional intake or to the benefit of the quality of the embryo. On the last day of the present experiment, Day 13, a trend can be observed in the eggs, wherein those produced by Treatment 1 were the largest (swollen by freshwater), followed by Treatment 2 with a size of 5 psu, which, in turn, is slightly larger than those produced via Treatment 3, with 9 psu. The eggs produced via Treatment 4 (12 psu), which corresponded to the highest salinity of all the treatments, presented the lowest volume. This finding may be related to the presence of more ions in the passage of the external medium into the embryo, as reported by [8], who also report $100 \%$ mortality in M. americanum larvae at Stage 5 of embryonic development at $0 \mathrm{psu}$ in green water. This finding differs with data obtained for $M$. rosenbergii in the present study, wherein $100 \%$ mortality was observed in larvae at Stage 2 (Treatment 1), which may be due to the fact that the study used clear water.

A tendency for a higher hatching percentage was observed for the higher salinity treatments than for the lower salinity treatments, which contrasts with that reported by [10], who found, in a study conducted on the embryonic development of $C$. caementarius, a higher hatching percentage at 0 psu than at both 10 and 20 psu. The foregoing contrast may indicate that $C$. caementarius reproduces in freshwater without problems, unlike the development of $M$. rosenbergii from embryogenesis onwards.

The survival percentage revealed by the present study shows a trend that is directly proportional to increased salinity, with Treatment 4 found to achieve the best rates of larvae survival once they have left the confines of the egg. The above finding concurs with that reported by [4], who, having applied six different treatments $(0,6,9,12,16$, and 18 $\mathrm{psu}$ ), reported an increasing survival rate (as a percentage) up to the $12 \mathrm{psu}$ treatment, with said rate then tending to decrease for the last two treatments. They also describe 12 psu as the best salinity of the levels studied [25], thus indicating salinity as a key factor for the larval development of $M$. rosenbergii.

The survival rate observed for Treatment 1 ( $0 \mathrm{psu})$ shows that hatching does not, in itself, guarantee survival, with the $100 \%$ mortality observed at Stage 2 of embryonic development, as described by [6]. This indicates that, while embryos tolerate increased water levels, larvae necessarily require saltwater in order for metamorphosis to occur. It is impossible for larvae to continue developing without saltwater, as [1] describe for M. americanum, finding 100\% mortality at 1 psu salinity, with no survivors observed by Day 2 of said treatment, and reporting almost $100 \%$ survival, up to Stage 3, for all the other treatments $(12,16,20,24$, and 26 psu) applied.

\section{Conclusions}

The conditions presented by an organism are a subsequent representation of the success or failure of the culture medium in which it has been grown. It is important to take into account the fact that the factors affecting success or failure vary depending on the geographical location in which the research is undertaken. The present research considered various factors in order to obtain a culture of high quality, ensuring that the development of the $M$. rosenbergii embryo occurred over practically the same hatching time, thus acquiring similar morphological features. A slight change in structure can be seen in eggs obtained at 0 psu (Treatment 1), 
where they are more fragile when handled and tend to break more easily, due to the amount of water they contain, thus causing the solvent to enter the egg in greater quantity and resulting in a greater volume. Moreover, the present study reveals the influence of temperature on embryonic development, which accelerates as the temperature increases $\left(29.5^{\circ} \mathrm{C}\right)$, while higher volumes do not necessarily entail optimal organisms, as the higher the salinity level, the higher the number of expected hatchings. However, the results of the present study show that Treatment 3, at 9 psu, obtained the highest hatching percentage (65\%), which was significantly higher than that obtained via Treatment 4 , at 12 psu (18\%), which indicates a good level of salinity, but in a measured proportion to embryonic development. Once the embryos had hatched, the larvae showed the foregoing salinity preference, wherein it was observed that, as salinity increased, survival also increased, with, of the salinity treatments applied, 12 psu (12.06\%) found to be the optimal level for larval development.

\section{References}

[1] Arica-García, E. B., y Barrientos-Gaona, J. A. (2013). Reproducción y desarrollo larval de camarón de río (Macrobrachium americanum) en laboratorio. Tesis de pregrado. Universidad Nacional de Tumbes, 27-35.

[2] Bas, C. C., y Spivak, E. D. (2000). Effect of salinity on embryos of two southwestern Atlantic estuarine grapsid crab species cultured in vitro. Journal of Crustacean Biology, 20 (4), 647-656.

[3] Bhujel, R. C. (2008). Statistics for aquaculture. Asian institute of technology. Thailand. John Wiley \& Sons.

[4] Buitrago, E. (1994). Efecto de la salinidad en el periodo de incubación de Macrobrachium rosenbergii. Estación de investigaciones marinas de Margarita. 216 (142).

[5] Charmantier, G. y Charmantier-Daures, M. (2001). Ontogenia de la osmorregulación en crustáceos: la fase embrionaria. Zoólogo estadounidense, 41 (5), 1078-1089.

[6] Chowdhury, R., Angell, C., y Bhattacharjee, H. (1993). A manual for operating a small-scale recirculation freshwater prawn hatchery. Madras: Bay of Bengal Programme.

[7] Coelho, P. A., Porto, M. R., y Soares, C. M. A. (1981). The culture of Macrobrachium bate (Decapoda, palaemonidae) in Brazil. Aquatic ecology; Nursery. Portuguese. Boletim Tecnico-Empresa de Pesquisa Agropecuaria do Rio Grande do Norte SA (Brazil). no. 6.

[8] Díaz-Monge, F., Díaz, M., y Rodríguez, R. (2001). Producción larval de camarón de río nativo, Macrobrachium americanum en laboratorio. Centro de Estudios del Mar y Acuicultura, Guatemala City.

[9] Dinakaran, G. K., Soundarapandian, P., y Varadharajan, D. (2013). Embryonic development of the palaemonid prawn Macrobrachium idella (Hilgendorf, 1898). Cell Dev Biol, 2 (111), 2 .

[10] Fuentes, A. S., Mogollón, A. V., y Reyes, W. E. (2010). Efectos de la salinidad sobre el desarrollo de embriones de
Cryphiops caementarius (Crustacea: Palaemonidae) incubados in vitro. Revista peruana de Biología, 17 (2), 215218.

[11] García-Guerrero, M. U., y Hendrickx, M. E. (2009). External description of the embryonic development of the prawn, Macrobrachium americanum Bate, 1868 (Decapoda, Palaemonidae) based on the staging method. Crustaceana, 1413-1422.

[12] García Guerrero, M. y Hernández Sandoval, P. (2012). Cambios totales de proteínas, lípidos, carbohidratos y agua de los huevos a través del desarrollo embrionario de Macrobrachium occidentale Holthuis, 1950 y su relación con los cambios morfológicos. Journal of Crustacean Biology, 32 (5), 769-773.

[13] Guest, W. C. (1979). Laboratory life history of the palaemonid shrimp Macrobrachium amazonicum (Heller) (Decapoda, Palaemonidae). Crustaceana, 37 (2), 141-152.

[14] Habashy, M. M., Sharshar, K. M., y Hassan, M. M. (2012). Morphological and histological studies on the embryonic development of the freshwater prawn, Macrobrachium rosenbergii (Crustacea, Decapoda). The Journal of Basic \& Applied Zoology, 65 (3), 157-165.

[15] Krebs, C. J. (1989). Ecological methodology (No. QH541. 15. S72. K74 1999.). New York: Harper y Row

[16] Ling SW (1969) The General Biology and Development of Macrobrachium rosenbergii (De Man). FAO Fish Rep. 57: 589-606.

[17] López Martínez, L. A (2004). Comportamiento y sistemas de producción de langostino (Macrobrachium sp.) /Luis Ángel, López Martínez (No. SH380. 2. M4. L66)

[18] Makombu, J. G., Oben, P. M., Oben, B. O., Gaudin, G. L., Motto, I. S., Makoge, N., y Mialhe, E. (2014). Complete Larval Development of the Fresh Water Prawn Macrobrachium vollenhovenii in Cameroon. Journal of Applied Aquaculture, 26 (4), 310-328.

[19] Mishra, P., y Dash, S. N. (2019). Embryonic development of Ganga river prawn Macrobrachium gangeticum (Bate). Aquaculture Research, 50 (6), 1687-1696.

[20] Müller, Y. M. R., Nazari, E. M., y Simões-Costa, M. S. (2003). Embryonic stages of the freshwater prawn Macrobrachium olfersi (Decapoda, Palaemonidae). Journal of Crustacean Biology, 23 (4), 869-875.

[21] Müller, Y., Ammar, D., \& Nazari, E. (2004). Embryonic development of four species of palaemonid prawns (Crustacea, Decapoda): pre-naupliar, naupliar and post- naupliar periods. Revista Brasileira de Zoologia, 21 (1), 27-32.

[22] Nandlal, S., y Pickering, T., (2005). Biology and life cycle. Freshwater prawn Macrobrachium rosenbergii farming in Pacific Island Contries (P. 4). Noumea, New Caledonia: Secretariat of the Pacific Community.

[23] Navarrete, E. O. (2005). Cultivo de langostinos. Boletín técnico. Instituto del mar del Perú (IMARPE).

[24] Nelson S. G., Armstrong D. A., Knight A. W. y Li H. W. (1977) The efects of temperature and salinity on the metabolic rate of juvenile. Macrobrachium rosenbergii (Crustacea: Palaemondiae). Comparative Biochemistry and Physiology 56A, 533-537. 
[25] New, M. B. (2002). Farming freshwater prawns. A manual for the culture of the giant river prawn (Macrobrachium rosenbergii). FAO Fisheries Technical Paper. FAO, Rome, Vol. 428-215 pp.

[26] Preston, N. (1985). The effects of temperature and salinity on survival and growth of larval Penaeus plebejus, Metapenaeus macleayi and M. bennettae. In Second Australian National Prawn Seminar (pp. 31-40). NPS2 Cleveland.

[27] SAGARPA (2011). Anuario Estadístico de Pesca 2011. Secretaría de Agricultura, Ganadería, Desarrollo Rural, Pesca y Alimentación, México

[28] Samuel, M. J., Kannupandi, T., y Soundarapandian, P. (1997). In vitro embryo culture and effect of salinity on the embryonic development of the cultivable freshwater prawn Macrobrachium malcolmsonii (H. Milne Edwards). Current Science, 294-297.

[29] Soundarapandian, P., Prakash, K. S., y Dinakaran, G. K. (2009). Simple Technology for the Hatchery Seed Production of Giant Palaemonid Prawn Macrobrachium rosenbergii (De Man). International Journal of Animal and Veterinary Advances, 1 (2), 49-53.
[30] Signoret G. y Brailousky, D. (2004). Adaptive osmotic responses of Macrobrachium acanthurus (Wiegmann) and Macrobrachium carcinus (Linnaeus) (Decapoda, Palaemonidae) from the southern Gulf of México. Crustaceana, 77 (4), 455-465.

[31] Sun, J., y Liu, D. (2003). Geometric models for calculating cell biovolume and surface area for phytoplankton. Journal of plankton research, 25 (11), 336.

[32] Vega-Villasante, F., Espinosa-Chaurand, L. D., YamasakiGranados, S., Cortés- Jacinto, E., García-Guerrero, M., CupulMagaña, A. L., y Guzmán-Arroyo, M. (2011). Acuicultura del langostino Macrobrachium tenellum Engorda de estanques semirústicos. Universidad de Guadalajara, Jalisco.

[33] Velázquez, E. E. J., y Gutiérrez, S. Q. B. (2017). Estructura de tallas de Macrobrachium tenellum (decapoda Palaemonidae) en el estero el salado, Puerto Vallarta, Jalisco, México. Biocyt: Biología, Ciencia y Tecnología, 10 (37), 656-671.

[34] Yávar, C., y Dupré, E. (2007). Desarrollo embrionario del camarón de río Cryphiops caementarius (Decapoda: Palaemonidae) en condiciones de laboratorio. Revista de Biología Tropical, 55 (Su1), 15-24. 